8. Kamins M. A. Promotional Bundles and Consumers' Price Judgments: When the Best Things in Life Are Not Free / Michael A. Kamins, Valerie S. Folkers, Alexander Fedorikhin // Journal of Consumer Research. - 2009. - Vol. 36. - P. 660-670.

DOI: http://doi.org/10.31617/k.knute.2019-03-19.79

\title{
МОЖЛИВОСТІ ЗАСТОСУВАННЯ АВТОМАТИЗОВАНИХ «РОЗУМНИХ» РЕКЛАМНИХ КАМПАНІЙ В GOOGLE
}

\author{
Яцюк Д. В. \\ к.е.н., доцент \\ кафедра журналістики та реклами \\ Київський національний торговельно-економічний університет, \\ Украӥна
}

Ключові слова: розумна рекламна кампанія, КМС, покоління великого пальия, соиіальний креатив.

Keywords: smart advertising.

Ecommerce-проекти завжди шукають нові можливості для свого онлайн-просування. Коли всі стандартні методики перестають працювати на максимізацію прибутку, бізнесу слід шукати нові вирішення своїх завдань [1].

Сьогодні інформаційні технології поглинають усі сфери людської діяльності: розумний дім, розумні девайси, інтерактивні магазини, VR/AR-технології та штучний інтелект стрімко завойовують популярність.

Розумні рекламні технології в цьому аспекті тільки починають свою експансію. Так, японське рекламне агентство McCann віддало посаду креативного директора - роботу. Грунтуючись на даних попередніх кампаній, штучний інтелект мав розробити рекламу для м'ятних льодяників Clorets. Ту ж задачу одночасно доручили людині. Обидві реклами виставили на голосування глядачів, і людина перемогла - але лише 3 результатом 54\% проти 46. У майбутньому, можливо, результат буде вже на користь штучного інтелекту [2]. Компанії, в тому числі і Google, все частіше застосовують штучний інтелект для автоматизації більшості процесів, в тому числі при створенні креативу, налаштуванні таргетингу, визначенні цінових стратегій тощо. Наразі тривають дослідження автоматичних алгоритмів, які найпевніше підтвердять ефективність оптимізації процесів. 
Цей матеріал присвячено вивченню можливостей «розумних» рекламних кампаній в Google, які базуються на застосуванні автоматизованих комп'ютерних алгоритмів. Розглянемо найбільш ефективні з них [3]:

1. Динамічна пошукова кампанія (DSA, орієнтована на feed завантаження даних)

Орієнтація на feed - ще досить новий інструмент, який зустрічається лише у $1 \%$ рекламних акаунтів. Відмінність таких DSAкампаній від стандартних полягає в можливості самостійно обирати, на які сторінки буде переходити користувач після кліку на оголошення. Це означає, що воно показується користувачам, які зацікавлені в конкретному товарі.

Контент в рекламних оголошеннях DSA-кампаній автоматично завантажується з feed-списку даних про товарні пропозиції або послуги. Таким чином можна розширити охоплення кампанії трафіком.

Ціна за клік у таких кампаній вище, оскільки в ній використовуються висококонкурентні пошукові запити. Однак при цьому i коефіцієнт конверсії у неї набагато вище, ніж у звичайної кампанії. Це пов'язано $з$ тим, що застосовуються запити більш релевантні оголошенням і сторінкам, а значить залученість користувачів вище.

2. Розумна КМС-кампанія (Smart Display).

Розумні КМС кампанії - черговий крок Google до повної автоматизації контекстної реклами.

Динамічний ремаркетинг дозволяє інтернет-магазинам показувати в Медійній мережі Google (KMC) рекламні оголошення 3 товарами, які користувачі переглядали на сайті, але так і не придбали. «Розумна» кампанія використовує дані 3 feed для підбору потенційних клієнтів. Хоча зовні вона нагадує динамічний ремаркетинг, iіi алгоритми працює інакше.

3. Використання динамічних оголошень завдяки застосуванню логічного оператора «if»

Використання логічного оператора «if» в рекламних оголошеннях допомагає краще персоналізувати їх для кінцевого користувача. 3 його допомогою можна динамічно змінювати тексти оголошень для власників певних девайсів (смартфони, планшети) і користувачів 3 списків і аудиторій.

Завдяки оператору «if» можна показувати певні оголошення при виконанні умов, зазначених при налаштуванні. Наприклад, якщо користувач входить в базу покупців інтернет-магазину, то йому потрібно демонструвати оголошення: «Знижка для постійних покупців $50 \%$ Я. Якщо ж користувач перейшов за посиланням зі смартфона, можна це вказати в тексті: «Знижка 25\% при оформленні замовлення зі смартфона» і т.д. 


\section{4. Розширення рекламних оголошень}

Розширення оголошення із зазначенням «Ціни», «Промоакції» дозволяє відображати необхідну користувачу інформацію під текстом оголошень про товари або послуги, що значно привалює потенційних покупців, у яких з'являється можливість порівняти, наприклад, цін, розмір знижки ще до переходу на сайт магазину.

Таким чином, автоматизовані «розумні» рекламні кампанії - це зручне і ефективне рішення, яке дозволяє враховувати безліч чинників в процесі управління рекламою. Тепер рекламодавцю не обов'язково націлювати, розраховувати ставки і створювати оголошення, тому що ці операції в розумних кампаніях автоматизовані.

Разом $з$ тим, для того, що мати можливість застосувати автоматизовані розумні кампанії в Google, необхідно щоб:

- за останні 30 днів в акаунті було мінімум 50 конверсій 3 контекстномедійної мережі або мінімум 100 - 3 пошукової;

- кампанія мала достатній бюджет на час навчання. Google рекомендує, щоб денний бюджет становив мінімум 10 цільових цін за конверсію, інакше кампанія просто не зможе коректно навчитися, досліджувати аудиторію і принести очікуваний результат.

Використовуючи розумні кампанії, рекламодавець демонструє свої оголошення практично будь-яких форматів та звертається до користувачів на різних етапах послідовності конверсії - від просто зацікавлених до тих, хто вже готовий зробити покупку. I цей процес побудований на використанні автоматизованих алгоритмів, розроблених штучним інтелектом.

Google Ads постійно поповнює список новацій, які підвищують ефективність онлайн-бізнесу. Вони полегшують досягнення цілей еcommerce-проектів, дозволяючи вигідно виділитися серед конкурентів і привести цільових клієнтів на сайт. Головне, зважено підходити до подібних пропозицій, попередньо тестувати обрані інструменти та з'ясовувати специфіку i різних нішах. Це допоможе заощадити рекламний бюджет, спрямувавши його на найефективніші канали.

\section{Список використаних джерел}

1.5 неочевидных приемов AdWords. - Режим доступа: promodo.ua/ blog/5-neochevidnyh-priemov-adwords.html

2. Евтушенко С. 10 технологий рекламы будущего. - Режим доступа: popmech.ru/commercial/295062-10-tekhnologiy-reklamy-budushchego

3. Умные кампании в контекстно-медийной сети. - Режим доступа: support.google.com/google-ads/answer/7020281?hl=ru 